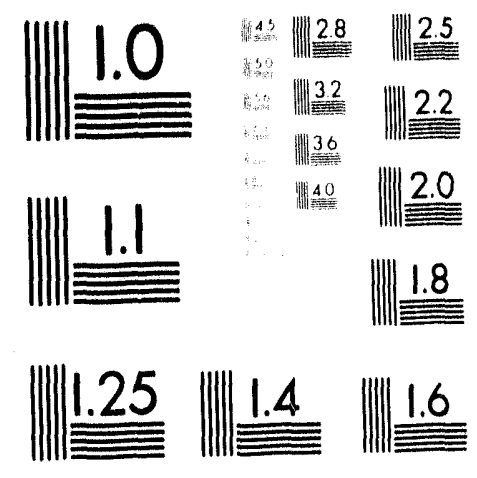



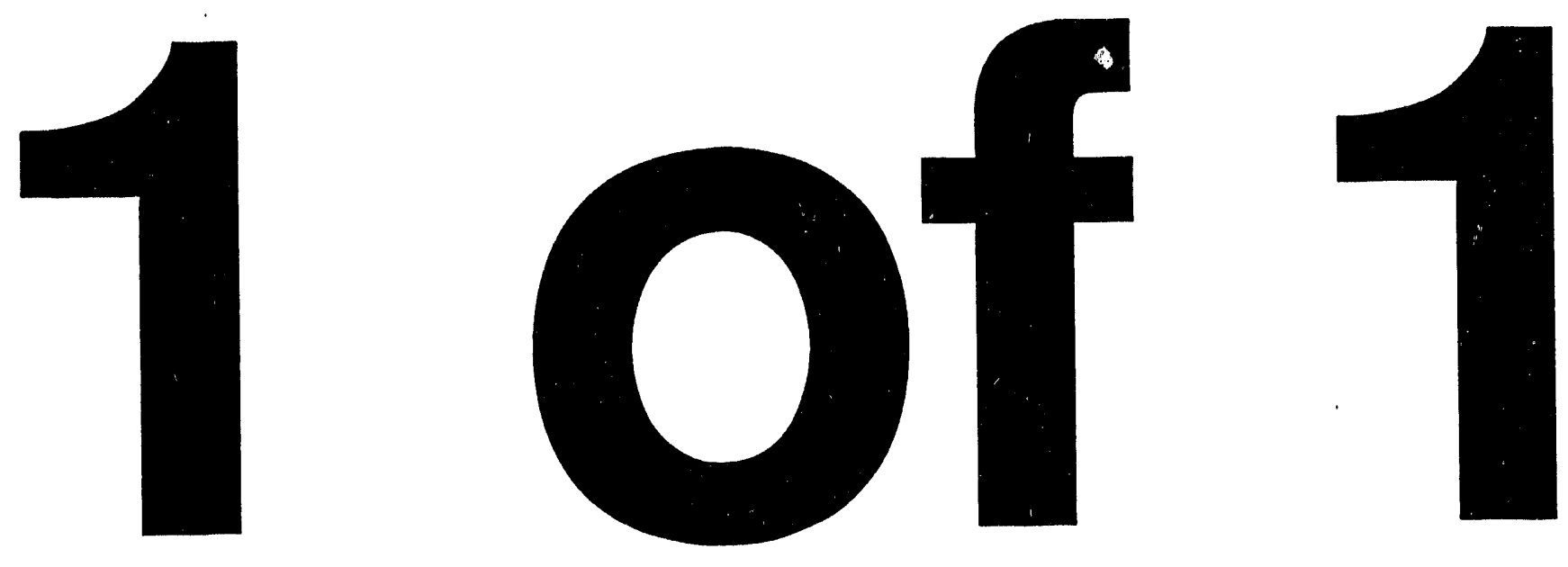


\title{
Thermomechanical Processing of $\mathrm{Ag}-\mathrm{Clad}$ $\mathrm{Bi}_{2} \mathrm{Sr}_{2} \mathrm{CaCu}_{2} \mathrm{O}_{x}$ Superconductors*
}

\author{
C.-T. Wu, K. C. Goretta, M. T. Lanagan, A. C. Biondo, \\ and R. B. Poeppel
}

Argonne National Laboratory, Argonne, IL 60439-4838 USA

\section{October 1993}

\begin{abstract}
The submilted menuscript has been authored by a contractor of the U.S. Government under contract No. W-31-100-ENG-38. Acoordingly, the U.S. Government retains a nonexchaivo, roy ally-iree licenses to publah or reproduce tio publinened form of this contribution, or allow othere to do 20 , for U.S. Oovernment purpoese.
\end{abstract}

\section{DISCLAIMER}

\begin{abstract}
This report was prepared as an account of work sponsored by an agency of the United States Government. Neither the United States Government nor any agency thereof, nor any of their employees, nakes any warranty, express or implied, or assumes any legal liability or responsibility for the accuracy, completeness, or usefulness of any information, apparatus, product, or process disclosed, or represents that its use would not infringe privately owned rights. Reference herein to any specific commercial product, process, or service by trade name, trademark, manufacturer, or otherwise does not necessarily constitute or imply its endorsement, recommendation, or favoring by the United States Government or any agency thereof. The views and of herein do not necessarily state or reflect those of the United States Government or any agency thereof.
\end{abstract}

Invited paper submitted to The Metallurgical Society Fall Meeting, Pittsburgh, PA, October 1721, 1993.

*Work supported by the U.S. Department of Energy (DOE), Energy Efficiency and Renewable Energy, as part of a DOE program to develop electric power technology, and Basic Energy Sciences-Materials Sciences, under Contract W-31-109-Eng-38. 
Thermomechanical Processing of $\mathrm{Ag}-\mathrm{Clad}$

$\mathrm{Bi}_{2} \mathrm{Sr}_{2} \mathrm{CaCu}_{2} \mathrm{O}_{x}$ Superconductors*

C.-T. Wu, K. C. Goretta, M. T. Lanagan, A. C. Biondo, and R. B. Poeppel

Argonne National Laboratory, Argonne, IL 60439-4838 USA

\begin{abstract}
$\mathrm{Bi}_{2} \mathrm{Sr}_{2} \mathrm{CaCu}_{2} \mathrm{O}_{\mathbf{x}}$ (2212) powders were synthesized by solid-state reaction, loaded into $\mathrm{Ag}$ tubes, and processed into tapes by various combinations of drawing, rolling, and heat treatment. Critical current densities at $4.2 \mathrm{~K}$ of greater than $10^{5} \mathrm{~A} / \mathrm{cm}^{2}$ were achieved from microstructures consisting of large, highly textured 2212 grains. Optimal microstructures were produced by specific mechanical-working conditions and heat-treatment schedules that incorporated solid-state and partial-melt sintering. The relationships between processing, microstructure, and critical current density will be discussed.
\end{abstract}


It has been shown that $\mathrm{Ag}$-sheathed $\mathrm{Bi}_{2} \mathrm{Sr}_{2} \mathrm{CaCu}_{2} \mathrm{O}_{x}(2212)$ tapes fabricated by the powderin-tube method have high current-carrying capability at $4.2-25 \mathrm{~K}$. Tenbrink et al. (1) used a partial-melting process for 2212 wire fabrication and produced a critical current density $\left(\mathrm{J}_{\mathrm{c}}\right)$ at $4.2 \mathrm{~K}$ exceeding $1\left(0^{4} \mathrm{~A} / \mathrm{cm}^{2}\right.$ to fields of $25 \mathrm{~T}$. Kase et al. (2) determined that large, highly caxis-aligned grains were developed by the use of partial-melt processing, which consisted of melting at $\approx 890^{\circ} \mathrm{C}$, followed by prolonged annealing at $\approx 870^{\circ} \mathrm{C}$. However, because of characteristics of the peritectic reaction, nonsuperconducting phases such as alkaline-earth cuprates, alkaline-earth bismuthates, $\mathrm{CaO}$, and $\mathrm{Cu}$ ) also formed. The alkaline-earth cuprates could grow quite large during cooling. These secondary phases disturb the local 2212 alignment and obstruct the current path, consequently decreasing $\mathrm{J}_{\mathrm{c}}$.

The optimum maximum temperature of the partial-melt process is reported to be $880-920^{\circ} \mathrm{C}$, depending on the stoichiometry of the 2212 and the atmosphere. $(1,2)$ However, the subsequent optimal annealing temperature and time are not so clearly defined. The 2212 phase will crystallize quickly from $\mathrm{Bi}-\mathrm{Sr}-\mathrm{Ca}-\mathrm{Cu}-\mathrm{O}$ glasses over a board range of temperature and time. (3) This implies that the annealing conditions for 2212 formation may not be critical. The purpose of this work was to clarify the relation between heat treatment and microstructure for 2212 tapes. The growth kinetics of the secondary phases and the effects of rolling conditions on $\mathrm{J}_{\mathrm{c}}$ were also studied.

\section{Experimental Details}

The Ag-clad tapes had the nominal cation molar content 2.0:1.7:1.0:2.0 (Bi:Sr:Ca:Cu). The starting powder was made by solid-state reaction of oxides and carbonates. (4) The phases after calcination were 2212 and trace amounts of $\mathrm{Bi}_{2} \mathrm{Sr}_{2} \mathrm{CuO}_{\mathrm{x}}(2201)$ and $\mathrm{CaO}$. The reacted powder was packed into an $\mathrm{Ag}$ tube and drawn and rolled to a tape $0.1-0.2 \mathrm{~mm}$ thick and $\approx 3 \mathrm{~mm}$ wide.

A series of quench experiments was conducted to monitor the kinetics of nucleation and growth of the superconducting and secondary phases. During heating, specirnens were quenched from $850,860,870,880$ and $890^{\circ} \mathrm{C}$. Two more specimens were quenched after 0.1 and $0.5 \mathrm{~h}$ holds at $890^{\circ} \mathrm{C}$. A $10^{\circ} \mathrm{C} / \mathrm{h}$ cooling rate was used to cool the tapes from $890^{\circ} \mathrm{C}$ to $880,870,865,860$ and $855^{\circ} \mathrm{C}$. Tapes were quenched after 1 and $3 \mathrm{~h}$ holds at $870,865,860$ and $855^{\circ} \mathrm{C}$. Rolled tapes (length $=5 \mathrm{~cm}$, width $=0.4 \mathrm{~cm}$, thickness $=0.2 \mathrm{~mm}$ ) were heated to the selected temperatures and then quenched into ice water. The distance between the quench medium and the outlet of the furnace was small to minimize the possibility of air quenching. Complete partial-melt heat treatments were also performed (Table 1). After partial-melt treatment, some tapes were rolled to $\approx 0.15 \mathrm{~mm}$ with various reductions per pass, and a final annealing treatment was conducied at $840^{\circ} \mathrm{C}$ in air for $100 \mathrm{~h}$.

Onsets of significant melting were determined by differential thermal analysis (DTA) in air. Phase identification and grain alignment of the tapes were determined by $\mathrm{X}$-ray diffraction 
(XRD) and scanning electron microscopy (SEM) with energy dispersive analysis of $X$-rays (EDS). Degree of $c$-axis alignment was defined as the ratio of the intensity of the (001) to the (117) peak. Current-voltage characteristics for Ag-clad tapes were measured by the conventional d.c. four-probe method at $4.2 \mathrm{~K} ; \mathrm{J}_{\mathrm{c}}$ was defined by a $1 \mu \mathrm{V} / \mathrm{cm}$ criterion.

Table 1. Partial-Melt Treatment of 2212 Tapes

Schedules Partial-melt Temp $\left({ }^{\circ} \mathrm{C}\right)$ Cooling Rate $\left({ }^{\circ} \mathrm{C} / \mathrm{h}\right)$ Holding Temp $\left({ }^{\circ} \mathrm{C}\right)$ Holding Time $(\mathrm{h})$

\begin{tabular}{lllll}
\hline 1 & 890 & 10 & 870 & 3 \\
2 & 890 & 10 & 865 & 3 \\
3 & 890 & 10 & 860 & 3 \\
4 & 890 & 10 & 855 & 3 \\
\hline
\end{tabular}

Results

Figure 1 shows the DTA curve of a typical Ag-sheathed 2212 tape. The endotherm at $\approx 884^{\circ} \mathrm{C}$ was due to incongruent melting of the 2212 phase. During cooling, an exotherm was observed between 865 and $850^{\circ} \mathrm{C}$. This peak, as will be discussed later, was due to solidification of 2212 phase. The delay in solidification relative to melting resulted because nucleation required undercooling to overcome the nucleation energy barrier to form critical nuclei.

Figure 2a shows the XRD data for tapes quenched from five different temperatures during cooling. No 2212 or 2201 formed from 880 to $865^{\circ} \mathrm{C}$. Small peaks of $(\mathrm{Sr}, \mathrm{Ca})_{2} \mathrm{CuO}_{3}(2.1)$ and $(\mathrm{Sr}, \mathrm{Ca}){ }_{14} \mathrm{Cu}_{24} \mathrm{O}_{\mathrm{x}}(14 / 24)$ were detected in this temperature range. (5) At $860^{\circ} \mathrm{C}$, the 2212 phase began to form; its intensity increased substantially at $855^{\circ} \mathrm{C}$. No significant texturing of 2212 grains was observed. The 2.1 and $14 / 24$ phases were also detected at 860 and $855^{\circ} \mathrm{C}$. XRD data of tapes quenched after $1 \mathrm{~h}$ at various temperatures are shown in Fig. 2b. After $1 \mathrm{~h}$ at $870^{\circ} \mathrm{C}$, no 2212 or 2201 was observed; 2212 formed at $865^{\circ} \mathrm{C}$, with a small amount of favorable texture. The texture was strongly developed after $1 \mathrm{~h}$ at $860^{\circ} \mathrm{C}$, but was less strong after holding at $855^{\circ} \mathrm{C}$. Figure $2 \mathrm{c}$ shows the XRD data of tapes quenched after $3 \mathrm{~h}$ at temperature. The results were similar to those shown in Fig. 2b. Again, the strongest caxis texture was developed at $\approx 860^{\circ} \mathrm{C}$ (Table 2).

Figure 3 shows SEM micrographs for various quenched tapes. Small amounts of needle-like alkaline-earth cuprate phases, $14 / 24$ by EDS, started to form at $860^{\circ} \mathrm{C}$ (Fig. 3a); average size was $\approx 100 \mu \mathrm{m}$ long and $\approx 10-20 \mu \mathrm{m}$ wide. As temperature increased to $880^{\circ} \mathrm{C}$, the secondary phases grew rapidly to $\approx 300-400 \mu \mathrm{m}$ in length, and the volume fraction increased (Fig. 3b). Above $880^{\circ} \mathrm{C}$, the $14 / 24$ phase decomposed and the 2.1 phase formed. After $0.5 \mathrm{~h}$ at $890^{\circ} \mathrm{C}$, the temperature was decreased at $10^{\circ} \mathrm{C} / \mathrm{h}$ to different temperatures. Figure $3 \mathrm{c}$ shows the microstructure of a tape quenched from $880^{\circ} \mathrm{C}$ during cooling. The size of the secondary phase remained about the same as that at $890^{\circ} \mathrm{C}$; however, the volume fraction increased. 


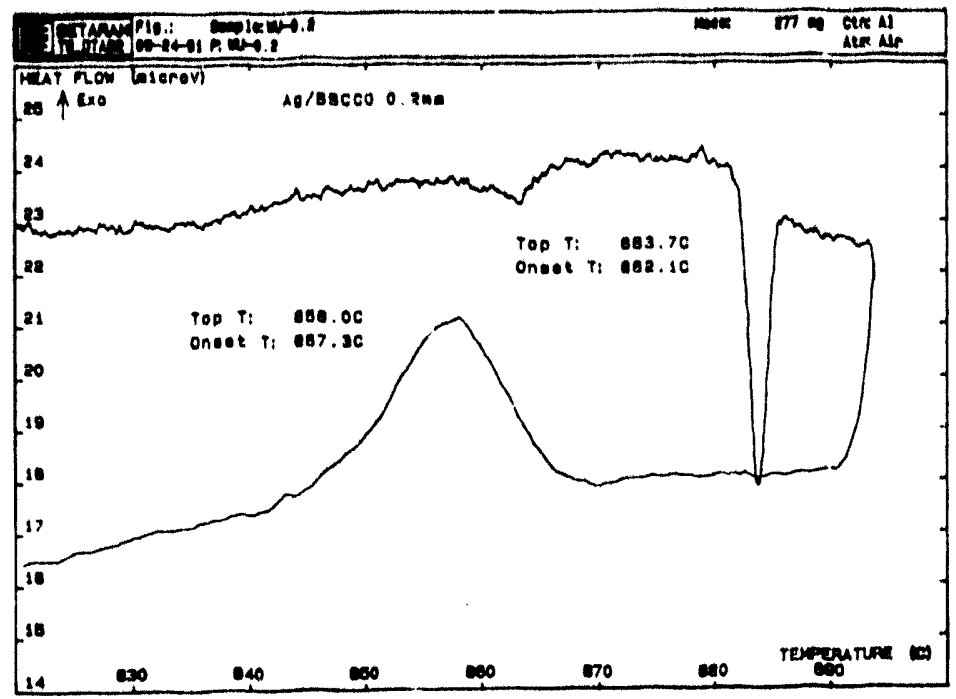

Figure 1. DTA Curve for Ag-Sheathed 2212 Tape

Table 2. The XRD Peak Ratio of (0010) to (117) of Quenched Tapes at Various Holding Temperatures and Times

\begin{tabular}{cccc}
\hline & $0 \mathrm{~h}$ & $1 \mathrm{~h}$ & $3 \mathrm{~h}$ \\
\hline $870^{\circ} \mathrm{C}$ & 0 & 0 & 0 \\
$865^{\circ} \mathrm{C}$ & 0 & 1.28 & 1.03 \\
$860^{\circ} \mathrm{C}$ & 1.36 & 1.97 & 2.03 \\
$855^{\circ} \mathrm{C}$ & 1.17 & 1.45 & 1.57 \\
\hline
\end{tabular}

Substantial coarsening of the secondary phases took place during the cooling from $880^{\circ} \mathrm{C}$ to $870^{\circ} \mathrm{C}$. In tapes quenched at $870^{\circ} \mathrm{C}$, secondary phase $800-1000 \mu \mathrm{m}$ long and $50-100 \mu \mathrm{m}$ wide were observed (Fig. 3d). EDS analysis indicated that these phases were 14/24. Smaller 2.1 phases (100-200 $\mu \mathrm{m}$ long, 10-20 $\mu \mathrm{m}$ wide) were also observed. Substantial growth of the platelike phases was observed after holding $3 \mathrm{~h}$ at $870^{\circ} \mathrm{C}$ (Fig. 3e). Large $14 / 24$ phases were also observed in the tapes quenched from 865 and $855^{\circ} \mathrm{C}$ (Figure $3 \mathrm{f}-\mathrm{h}$ ). In particular, remarkable coarsening occurred after $3 \mathrm{~h}$ at $865^{\circ} \mathrm{C}$. However, no coarsening occurred after 3 $h$ at $855^{\circ} \mathrm{C}$. Little coarsening of the 2.1 occurred for any cooling schedule. The volume fractions of the 14/24 and 2.1 as a function of quenching temperature during heating and cooling are shown in Figs. 4 and 5. The volume fraction of 14/24 phase as a function of holding time at various temperatures is shown in Fig. 6. Substantial increases occurred with holding at 870 and $865^{\circ} \mathrm{C}$, but not at $860^{\circ} \mathrm{C}$ and $855^{\circ} \mathrm{C}$.

SEM micrographs for tapes after full partial-melt heat treatments are shown in Fig. 7 . The dominant phase was 2212 , but small amounts of 2201 were always observed. Figure 7 a shows a tape annealed $3 \mathrm{~h}$ at $865^{\circ} \mathrm{C}$. Well-aligned 2212 grains developed near the $\mathrm{Ag}$ interface, producing a structure favorable for passage of electrical current. 


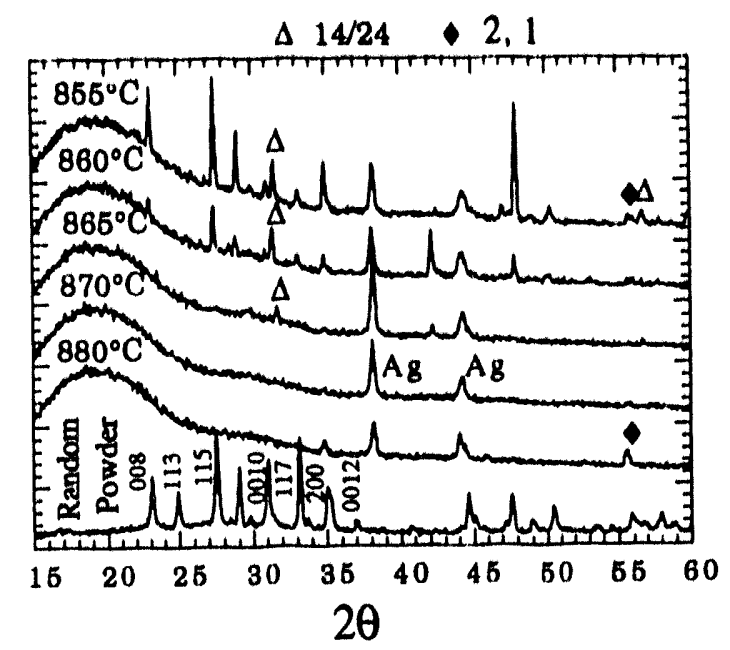

(a)

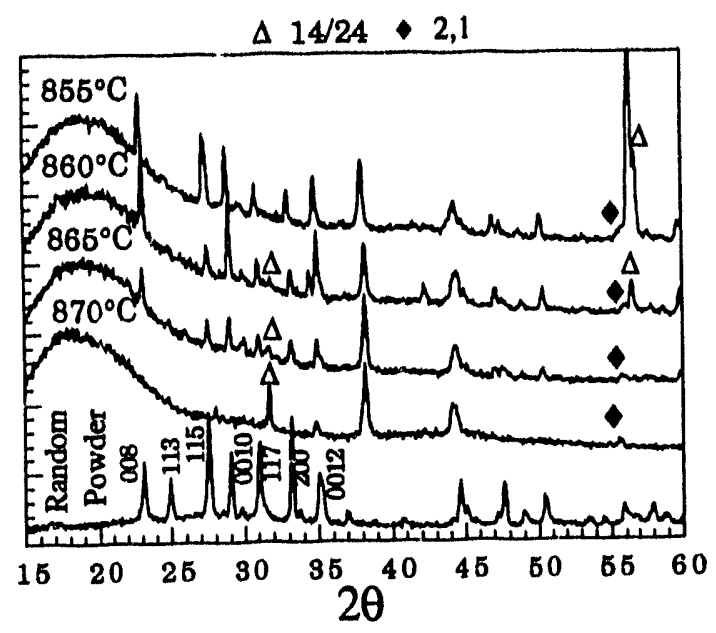

(b)

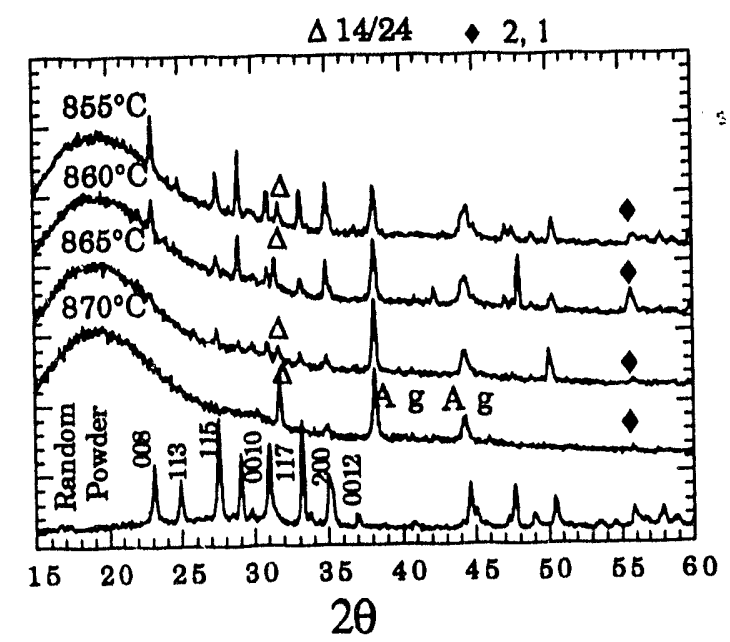

(c)

Figure 2. XRD for the Tapes Quenched After (a) $0 \mathrm{~h}$, (b) $1 \mathrm{~h}$, (c) $3 \mathrm{~h}$ Holds at Various Temperatures, with a Cooling Rate of $10^{\circ} \mathrm{C} / \mathrm{h}$ from $890^{\circ} \mathrm{C}$ 

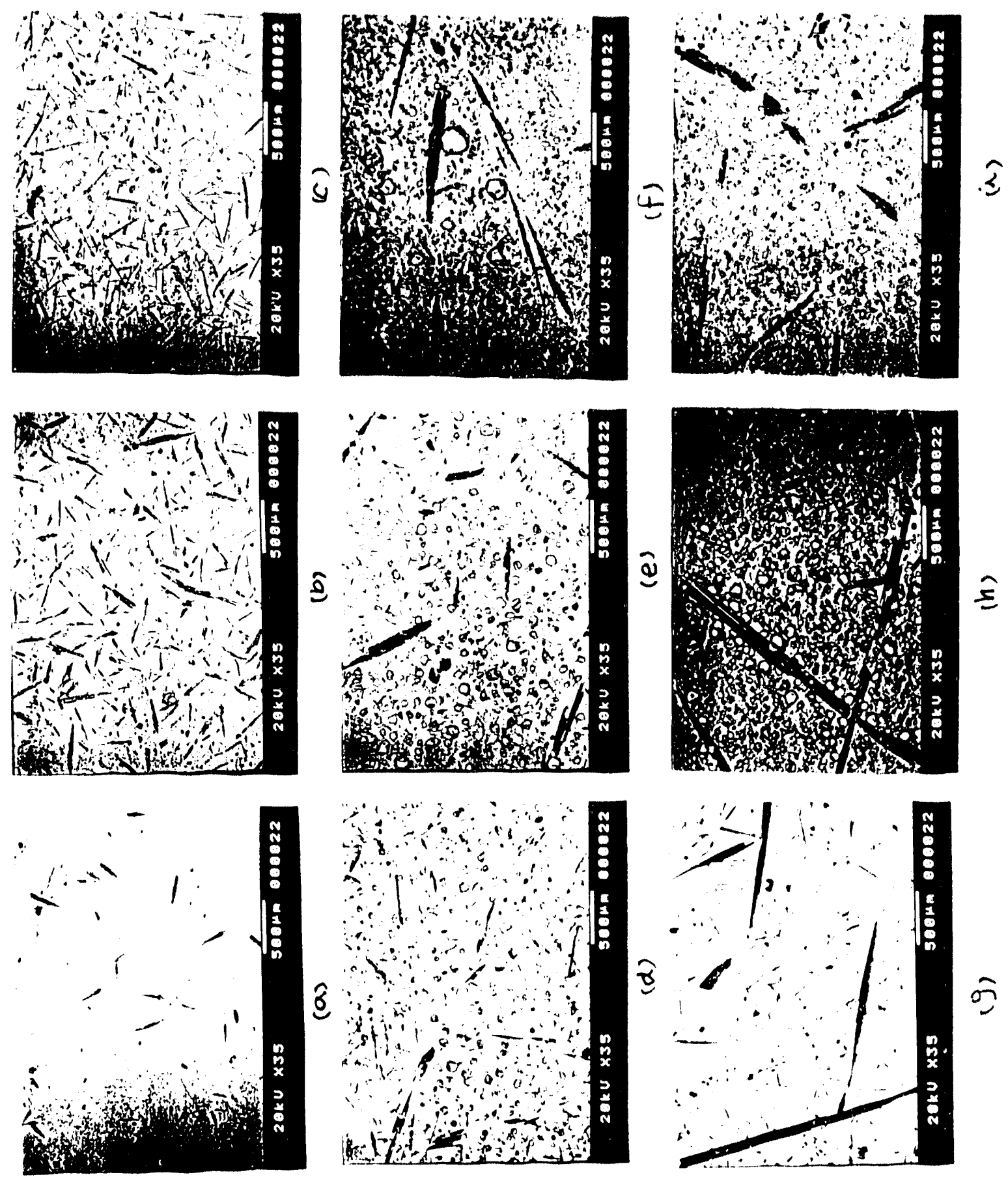

Figure 3. Microstructure of Tapes Quenched from Various Holding Temperatures and Times on Heating and Cooling 


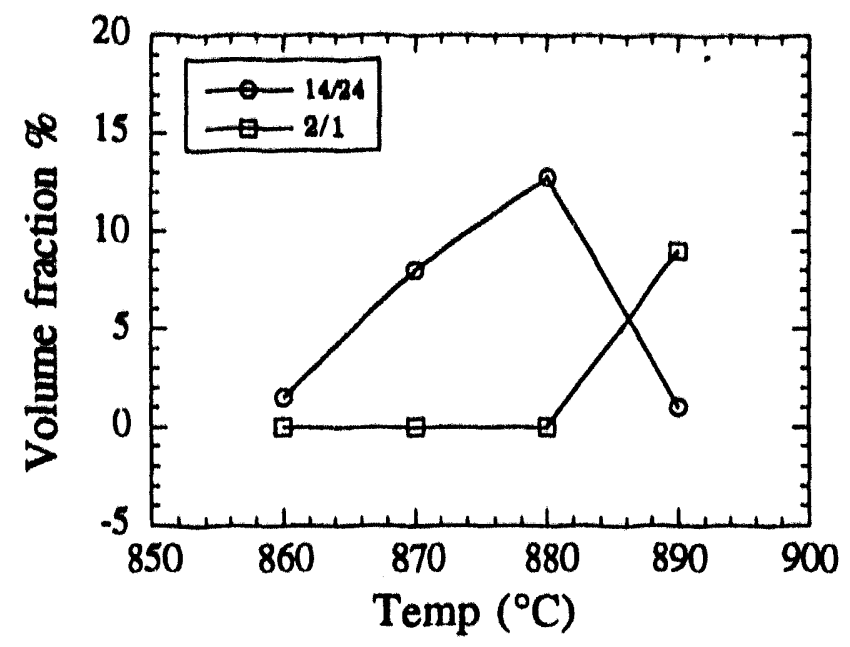

Figure 4. Volume Fraction of Secondary Phases as a Function of Temperature upon Heating

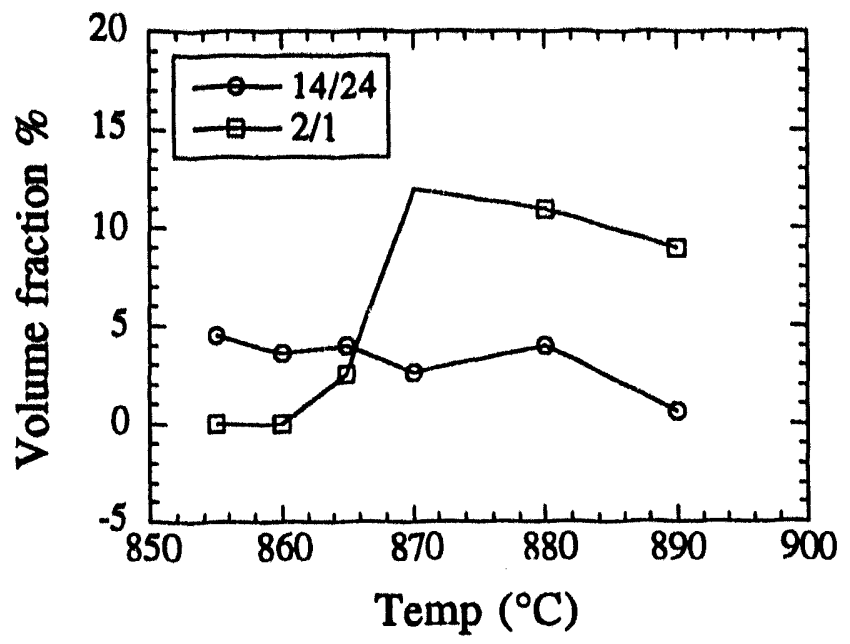

Figure 5. Volume Fraction of Secondary Phases as a Function of Temperature upon Cooling

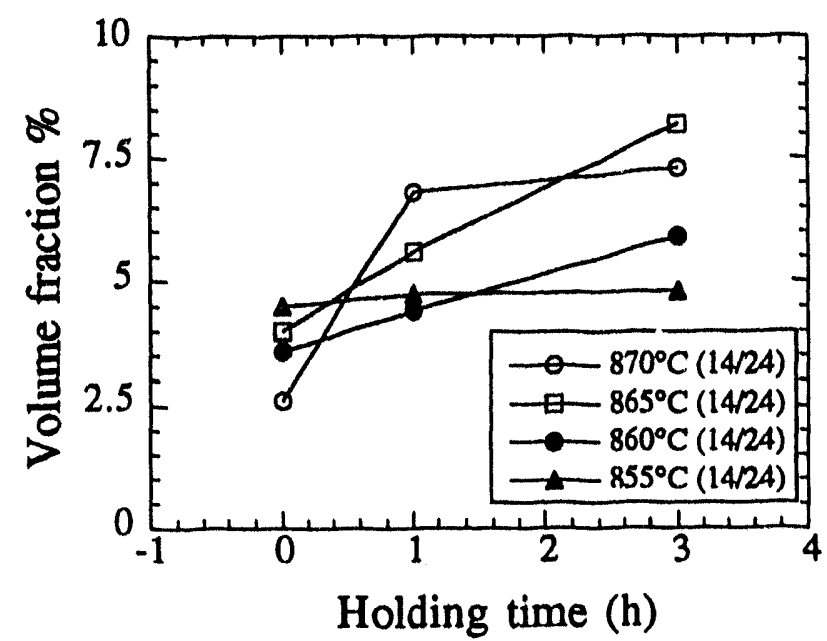

Figure 6. Volume Fraction of $14 / 24$ as a Function of Annealing Time at Temperature 
However, some 2212 grains adjacent to secondary phases grew along the interface, and thus the growth direction was not parallel to the rolling direction. In addition, some 2212 grains stopped growing when their growth fronts were obstructed by secondary phase. Presence of large second phases reduced the extent of favorable texture. The microstructure of tapes annealed at $860^{\circ} \mathrm{C}$ is shown in Fig. 7b. Well-aligned grains were present throughout the entire oxide core. Some 2201 (lighter gray) grains were embedded between the 2212 (darker gray) grains. The microstructure of tapes annealed $3 \mathrm{~h}$ at $855^{\circ} \mathrm{C}$ is shown in Fig. 7c. The desired well-aligned grain structure was only present near the $\mathrm{Ag}$ interface. Randomly oriented grains were present throughout the central zone of the oxide core. In addition, some 2212 grains penetrated into $\mathrm{Ag}$ and disrupted the well-textured structure at the $\mathrm{Ag}$ interface.

The $\mathrm{J}_{\mathrm{c}}$ values for the tapes after partial-melting treatment, but before final rolling and heat treatment at $840^{\circ} \mathrm{C}$, are shown in Fig. 8 . Highest $\mathrm{J}_{\mathrm{c}}$ values were produced by annealing at $860-865^{\circ} \mathrm{C}$. A tape that was held $3 \mathrm{~h}$ at $860^{\circ} \mathrm{C}$ in partial-melt step and final annealed $100 \mathrm{~h}$ at $840^{\circ} \mathrm{C}$ yielded the highest $\mathrm{J}_{\mathrm{c}}$ at $4.2 \mathrm{~K}, 1.5 \times 10^{5} \mathrm{~A} / \mathrm{cm}^{2}$. The highest $\mathrm{J}_{\mathrm{c}}$ value was produced by rolling with $10 \%$ reduction per pass; larger reductions per pass decreased $\mathrm{J}_{\mathrm{c}}$ values about $50 \%$. (4) The effect of annealing time at $840^{\circ} \mathrm{C}$ on $\mathrm{J}_{\mathrm{c}}$ is shown in Fig. 9. In this processing, at least $\approx 100 \mathrm{~h}$ was needed to produce a high-J $\mathrm{J}_{\mathrm{c}}$ tape.

\section{Discussion}

The broad exotherm on the DTA curve ranged between 865 and $850^{\circ} \mathrm{C}$. Maximum heat was released from this system at $=857^{\circ} \mathrm{C}$. If the heat of this exotherm is due to latent heat released by solidification of 2212 , this curve indicates that the nucleation process of 2212 started at $\approx 865^{\circ} \mathrm{C}$ and the maximum number of nuclei formed at $\approx 857^{\circ} \mathrm{C}$. XRD analysis of tapes quenched during cooling shows that no 2212 phase forms until $860^{\circ} \mathrm{C}$ during continuous cooling. 2212 peaks were observed after $1 \mathrm{~h}$ at $865^{\circ} \mathrm{C}$. No 2212 formed at $870^{\circ} \mathrm{C}$. These results confirm that the DTA exotherm was due to solidification 2212. XRD data for the tapes quenched after $1 \mathrm{~h}$ at various temperatures during cooling indicate that better texture of 2212 was obtained at $860^{\circ} \mathrm{C}$ than at $855^{\circ} \mathrm{C}$. In addition, the grains of the tapes annealed $3 \mathrm{~h}$ at $865^{\circ} \mathrm{C}$ and $860^{\circ} \mathrm{C}$ exhibited better alignment than in tapes annealed at $855^{\circ} \mathrm{C}$. High $\mathrm{J}_{\mathrm{c}}$ was produced by heat treatment at 865 and $860^{\circ} \mathrm{C}$. The $\mathrm{XRD}, \mathrm{SEM}$, and $\mathrm{J}_{\mathrm{c}}$ results indicate that a tape with better microstructure, primarily maximum c-axis alignment, and better electrical properties can be produced by cooling from $890^{\circ} \mathrm{C}$ to $860-865^{\circ} \mathrm{C}$, holding there for about $3 \mathrm{~h}$, and cooling to room temperature. Generally speaking, low nucleation rates and high growth rates during phase transformations or solidification are required for a large-grained microstructure. The desired structure for good electrical properties of high- $\mathrm{T}_{\mathrm{c}}$ superconductor is one in which the grains are large and aligned parallel with the direction of current flow. Kase et al. (2) found that 2212 grains nucleated easily and grew rapidly along Ag interfaces. A 20- $\mu$ m-thick layer of well-aligned 2212 grains parallel with $\mathrm{Ag}$ interface was formed at the interface during cooling from $890^{\circ} \mathrm{C}$ to $870^{\circ} \mathrm{C}$. It is believed that this thin well-aligned grain layer is the major region of current flow. (2) The thicker this layer, the higher $\mathrm{J}_{\mathrm{c}}$. Therefore, the effort is to find a proper partial-melt schedule to increase the thickness of this well-aligned 


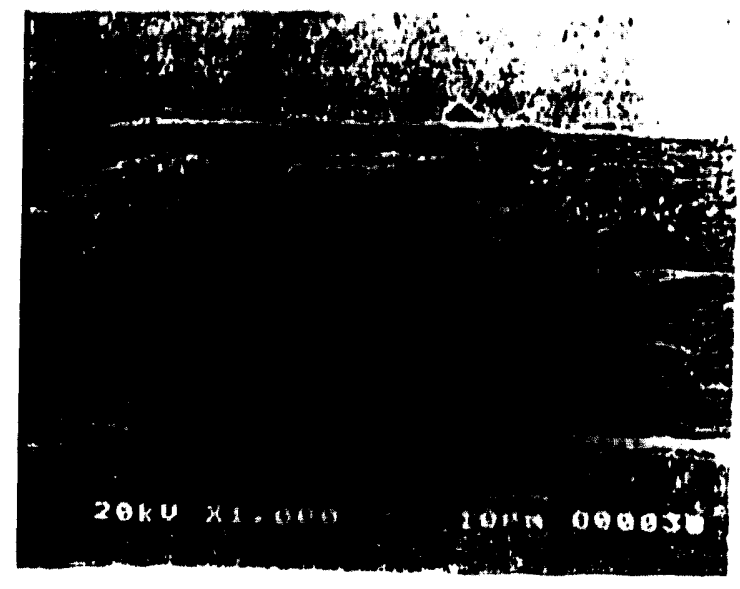

(a)

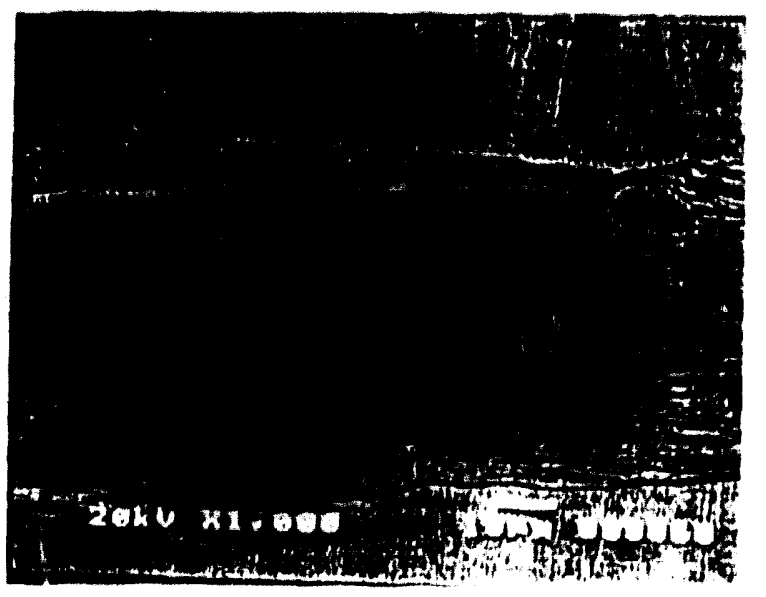

(b)

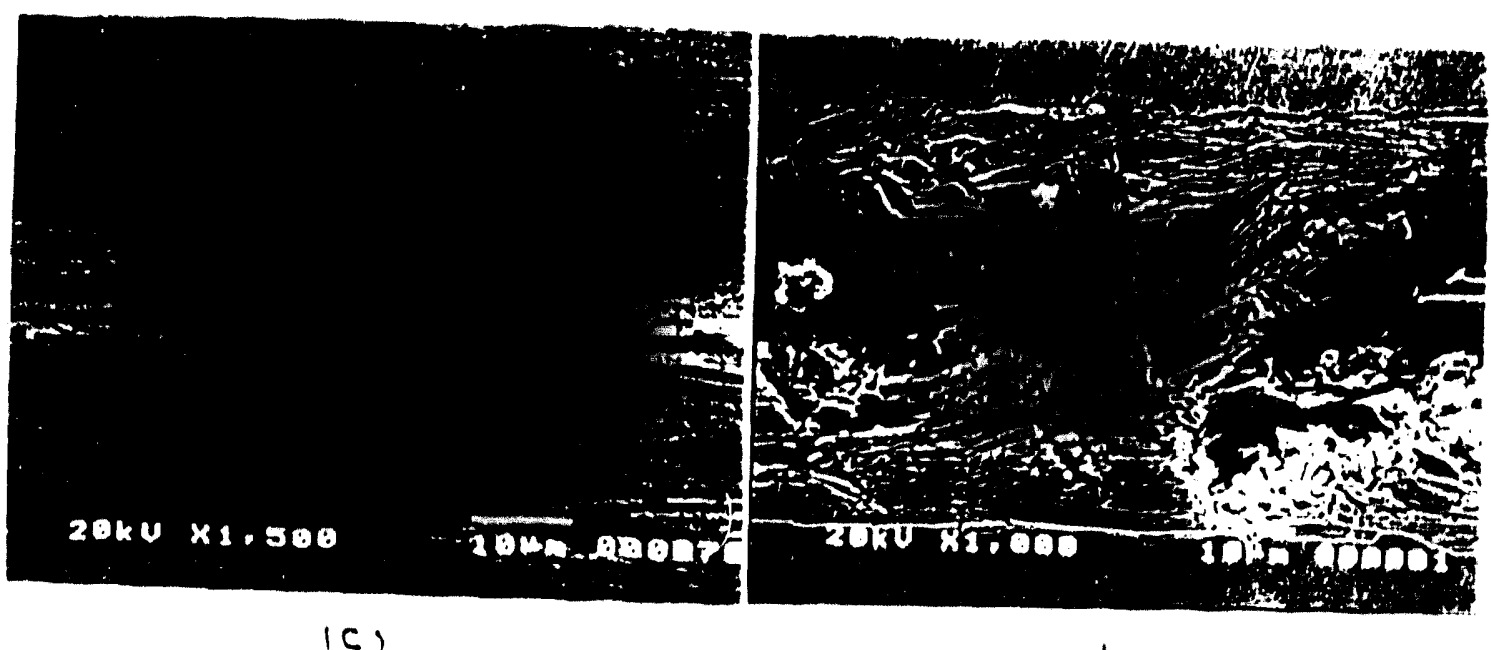

(d)

Figure 7. SEM Microstructure of Tapes Partially Melted with (a) Schedule 1. (b) Siche dule 2. (c) Schedule 3. and (d) Schedule 4. as listed in Tahle I 


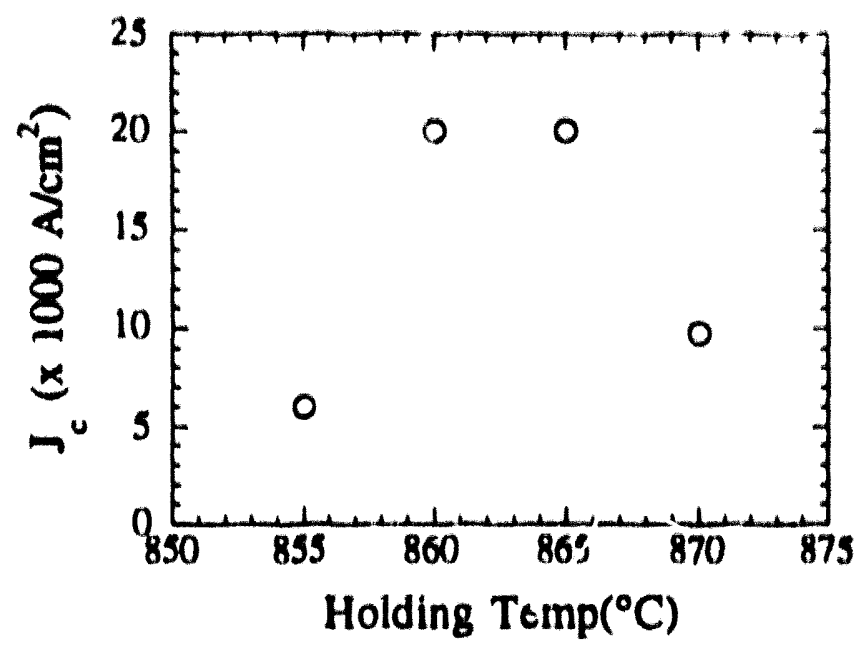

Figure 8. $\mathrm{J}_{\mathrm{c}}$ at $4.2 \mathrm{~K}$ for Tapes Heat Treated by Schedules Listed in Table 1

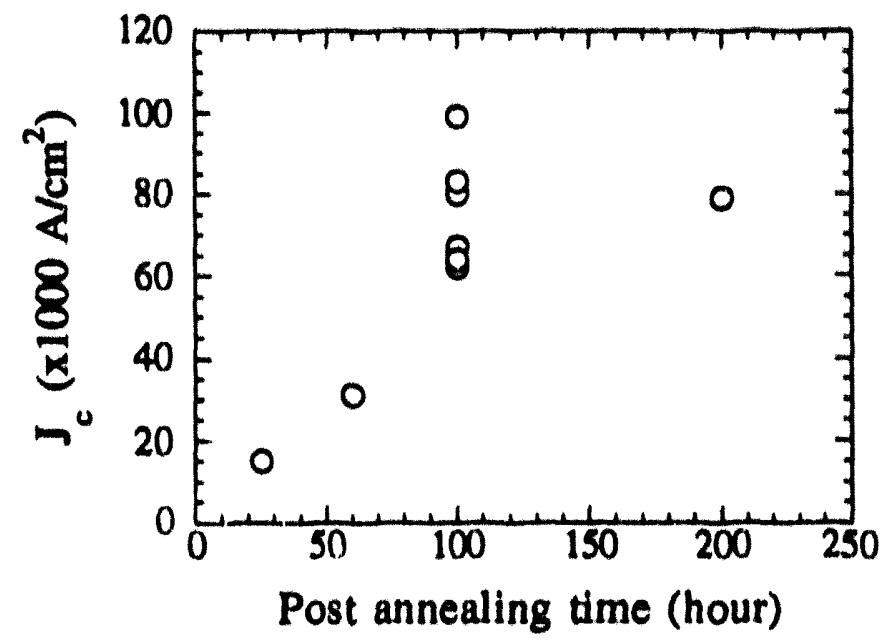

Figure 9. Relationship between $\mathrm{J}_{\mathrm{C}}$ and Sintering Time at $840^{\circ} \mathrm{C}$ in Air

grain structure near the $\mathrm{Ag}$ interface. $\mathrm{Ag}$, essentially acting as a mold wall in the solidification process, is a favorable site for heterogeneous nucleation of 2212 . However, due to the secondary phase present in the BSCCO oxide core, 2212 can also nucleate on these particles easily and, because of the random distribution of these secondary phase, the growth directions of the 2212 are also random.

The grain structure produced during partial-melt processing is determined by competition between growth of 2212 in two regions: first, is the region near the $\mathrm{Ag}$ interface where the 2212 grains are well-aligned, and second is the region near the center of the oxide core where the 2212 grains may grow along interfaces with secondary phases. It has been found that addition of $\mathrm{Ag}$ to 2212 can drop the melting point by $-15^{\circ} \mathrm{C}$. (4) Fang et al. (6) showed that diffusivity of $\mathrm{Ag}$ is high at high temperature. It is possible that there exists a layer of the core near the Ag interface in which the melting point is lowered because of the presence of Ag. As 
a reqult, mure liquid may be present in this $\mathrm{Ag}$-rich layer than in areas with less $\mathrm{Ag}$. This liquid tich mone near the $A_{B}$ interface may promote growth of 2212 after it has nucleated on the Ay. In the partial melt process used here, $860-865^{\circ} \mathrm{C}$ is good for the desired grain structure, because of a low rate of nucleation and because of high growth rates due to the presence of liyuld. However, conrsening of secondary phases takes place at $\approx 865^{\circ} \mathrm{C}$ and higher lemperafures. These course secondary phases have a deleterious effect on the overall alignment of 2212. Therefore, the holding temperature following partial melting should be at a lemperature below that favored for coarsening of secondary phase. At $855^{\circ} \mathrm{C}$, more nuclei are formed in the oxide and the thickness of the liquid-rich layer may be less than that at hig cemperature. As a result, thin layers of well-aligned grain structure near the $\mathrm{Ag}$ intei re and random sinuclures at the center are produced.

The highest $J_{c}$ value after the partial-melting process was $\approx 2 \times 10^{4} \mathrm{~A} / \mathrm{cm}^{2}$, which is below the value needed for most practical applications. The low $\mathrm{J}_{\mathrm{c}}$ may be attributed to several reasons. Hint. due to the retrograde densification associated with anisotropic grain growth, the density of the oxide core decreased after partial melting. (7) Second, pores may have been generated during heating because of decomposition of residual carbonates or hydroxides (8), or sudden evolution of oxygen upon decomposition of the 2212. (9) Further rolling redensified the core and enhunced $c$-axis alignment by mechanical action. Post annealing was employed to connect the gruins and heal the smull cracks that may have been generated during the second folling. However, severe mechanical working may result in irreparable damage, such as large cracks and sausaging. SEM revealed that sausaging was most pronounced in tapes with high concentrutions of secondary phases. It appears that gradual and limited mechanical working in fuvorable for high current capability.

\section{Assessment}

The partial-melting process substantially affects the final microstructure and $\mathrm{J}_{\mathrm{c}} \mathrm{Ag}$-clad 2212 tupes. Parameters to be controlled in this process are: atmosphere, maximum temperature, holding time at temperuture, and heating and cooling schedules. The structures of 2212 and the secondary phase vary with these parameters, and consequently, electrical properties vary as well. In the second rolling step, severe reduction may cause damage; moderate reduction cun densify the core structure, without introducing serious damage to the core. However, due to the size of the secondary phase, the thickness after the second roll can be limited. A post annealing process is essential to heal the cracks which are generated during rolling and to join the superconducting grains.

\section{Acknowledgemeut}

We thank C. A. Youngdahl and J. S. Kallend for advice and experimental assistance. This work was supported by the U.S. Department of Energy (DOE), Offices of Energy Efficiency and Rencwable Energy, as part of a DOE program to develop electric power technology, and Basic Energy Sciences-Materials Sciences, under Contract W-31-109-Eng-38. 


\section{Beferences}

1. J. Tenbrink et al., "Deveolopment of High-T $\mathrm{T}_{\mathrm{c}}$ Superconductor Wires for Magnet Applications," presented at the Applied Superconductivity Conf., Snowmass Village, CO (September 24-28, 1990).

2. J. Kase, "Preparation of the Textured Bi-Based Oxide Tapes hy Partial Melting Process," presented at the Applied Superconductivity Conf., Snowmass Village, CO (September 24-28, 1990).

3. T. G. Holesinger, D. J. Miller, and L. S. Chumbley, L. Mater Res. 7, 1658-1671 (1992).

4. C.-T. Wu, K. C. Goretta, and R. B. Poeppel, "Effects of Processing Parameters on Critical Current Density of $\mathrm{Ag}-\mathrm{Clad} \mathrm{Bi}_{2} \mathrm{Sr}_{2} \mathrm{CaCu}_{2} \mathrm{O}_{\mathrm{x}}$ Tapes," Applied Superconductivity 1, $263-267$ (1992).

5. R. D. Ray II and E. E. Hellstrom, "Phase Development in Ag-Clad BSCCO Wires," High Temperature Superconductors: Eundamental Properties and Novel Materials Processing, (Pittsburgh, PA: MRS, 1990), pp. 1291-1294.

6. Y. Fang et al., "Trace Diffusion of ${ }^{110} \mathrm{Ag}$ in $\mathrm{Bi}_{2} \mathrm{Sr}_{2} \mathrm{CaCu}_{2} \mathrm{O}_{\mathrm{x}}$," Appl. Phys. Lett. 60 (18), 4 May 1992 pp. $2291-2293$

7. D. W. Johnson, and W. W. Rhodes, "Retrograde Densitication in $\mathrm{Bi}_{2} \mathrm{Sr}_{2} \mathrm{CaCu}_{2} \mathrm{O}_{8}$ Superconductcrs," I. Am. Ceram. Soc., 72 (12) (1989), pp. 2346-2350.

8. Yan, M. F., "Conventional Ceramics Processing of High-T $\mathrm{C}_{\mathrm{c}}$ Superconductors," Better Ceramics Through Better Chemistry III, ed. Brinker, C. J., Clark, D. E. and Ulrich, D. R. (Pittsburgh, PA: MRS, 1988), pp. 385-400.

9. Almond, D. P., Chapman, B. and Saunders, G. A., "The Properties of Quenched Bi-Ca$\mathrm{Sr}-\mathrm{Cu}$ Oxide Superconductors," Supercond. Sci. Technol., 1 (1988), p. 123 

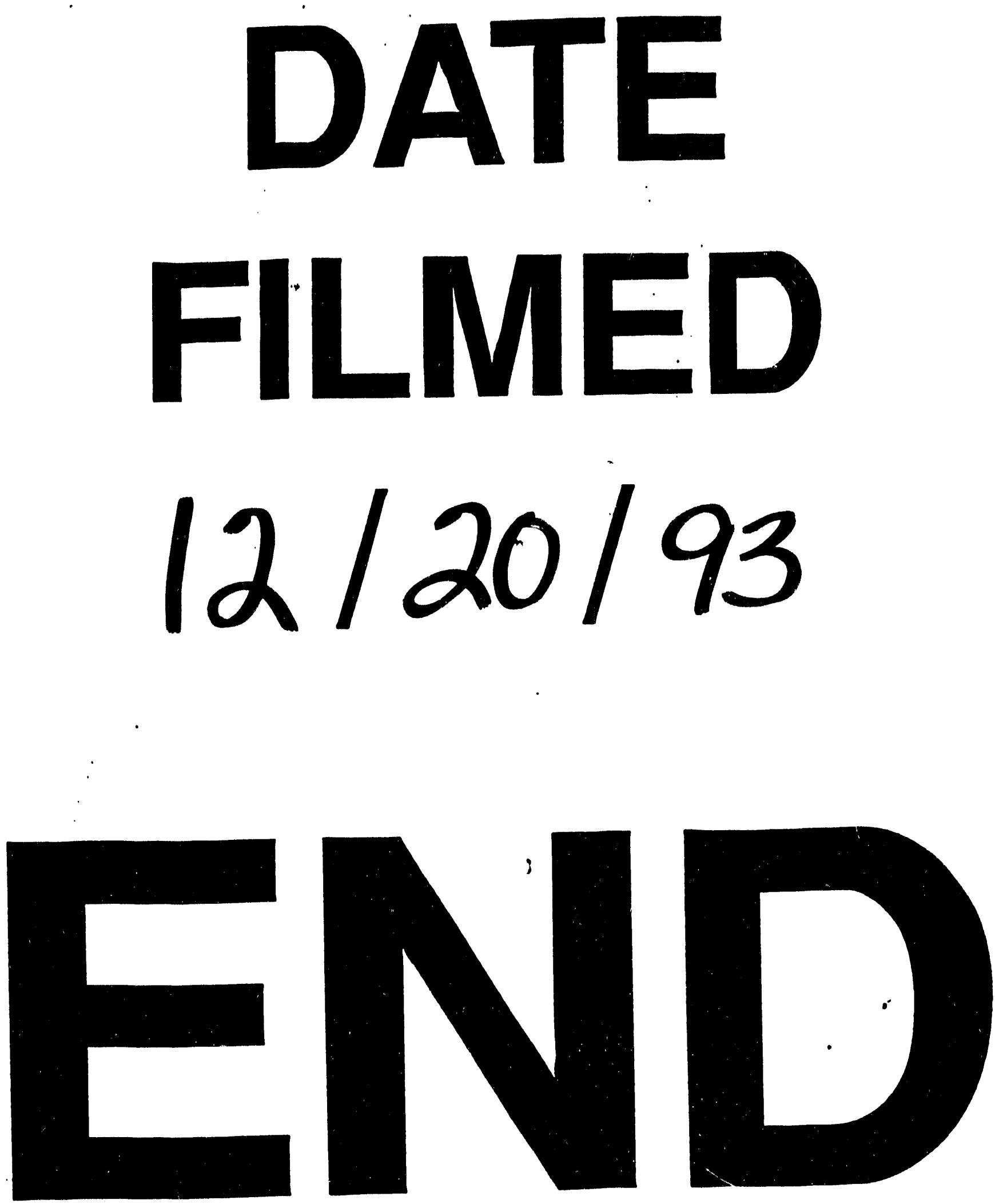


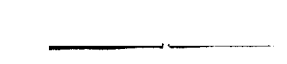

